\title{
Anphitheatrical Rio! Marítimos americanos na baía do Rio de Janeiro. Século XIX ${ }^{2}$
}

Anphitheatrical Rio! American

Seamen in the Bay of Rio de Janeiro.

Nineteenth century

\section{Silvana Cassab Jeha \\ Doutora em História pela Pontifícia Universidade Católica do Rio de Janeiro (PUC - Rio de Janeiro/Brasil) e-mail: silvanajeha@gmail.com}

\section{Resumo}

A narrativa marítima americana foi pouco consultada na historiografia brasileira. São diários, livros de memórias e ficção de marinheiros comuns e oficiais, que incluem autores como Herman Melville e dezenas de homens, praticamente desconhecidos, que escreveram sobre suas estadias no Império do Brasil, principalmente na primeira metade do século XIX, fim da era dos veleiros. Este artigo trata de suas experiências no porto do Rio de Janeiro, procurando demonstrar como a presença estadunidense foi intensa e narrada. Estes tipos de testemunhos são fontes importantes para a história da cidade e para a inclusão do Rio de Janeiro na história marítima internacional, como uma das escalas mais importantes nas rotas de longo curso no período.

\section{Abstract \\ The American sea narratives are seldom read by the Brazilian historiography. These narratives, composed by diaries, memoirs and fiction common seamen and officers (such as Herman Melville and virtually unknown men), tell us about their experiences in the Empire of Brazil mainly in the first half of nineteenth century, when the age of sail came to an end. This article deals with their experiences in the port of Rio de Janeiro, trying to demonstrate how the North American presence was intense and narrated. These types of testimonials are important sources for the history of the city and for the inclusion of Rio de Janeiro in international maritime history as one of the most important scales in long-haul routes in the period.}

\section{Palavras-chave}

narrativas marítimas, maritimos estadunidenses, Império do Brasil, Portos, Rio de Janeiro, século XIX

\section{Keywords}

Expressão de Herman Melville na novela WhiteJacket or the world in a man-of war.

2

Este artigo é resultado de uma bolsa de pósdoutorado Reuni/Sesu da CAPES, vigente entre junho e dezembro de 2012, no programa de Pós-Graduação da UNIFESP. Nesta pesquisa aprofundei o estudo de uma parte das fontes utilizadas na minha tese de doutorado: narrativas de marinheiros americanos que estiveram no Brasil. Todas as traduções de textos originais em inglês são minhas. sea narratives, American seamen, Empire of Brazil, Ports, Rio de Janeiro, XIXth century 
MELVILLE. Herman. White-Jacket, or the world in a man-of war. New York: Library of America, 1983 [1851]. p.593. Parte autobiográfico, parte ficção, o navio de fato aportou no Rio de Janeiro do dia 16 a 24 de agosto de 1844. Segundo Willard Thorp, Dom Pedro não teria visitado o navio. THORP, Willard. Historical Note. In: White-jacket or the world in a man-of-war. The Northwestern-Newberry Edition, 1988. p.403440. No final do texto há uma lista de biografias minimas dos autores que tratarei.

Ibidem, p.596.

THOMPSON, George (pseud.). The story of a strange career: The autobiography of a convict, an authentic document. Ed. Stanley Waterloo. New York: D. Appleton \& Co. 1902. p.86.

6

Escolhi usar a palavra americano no lugar de norte-americano ou estadunidense, pois é o termo empregado nos documentos consultados.

7

Neste artigo adoto a expressão baía do Rio de Janeiro no lugar de baía de Guanabara, pois era o termo usado pelos estrangeiros no século XIX.

8

Zona portuária entendida aqui como toda a baia, ilhas e navios ancorados, o porto em si, docas, armazéns, bordéis, estalagens, tavernas especializados em marítimos, ancoradouros e bairros inteiros.

9

Port city, traduzido como cidade portuária, é um conceito multidisciplinar das ciências sociais. 0 geógrafo César Ducruet enumera diversas definições, levando em consideração sua "diversidade e evolução constante". A definição mais simples seria "uma cidade que exerce atividades portuárias e atividades marítimas". Segundo este autor, uma outra definição, utilizada principalmente por historiadores é "uma cidade onde porto e atividades marítimas têm tanta influência na economia local, que a cidade depende do porto para existir". DUCRUET, César. The port city in multidisciplinary analysis (author manuscript, published in The port city in the XXIst century: New challenges in the relationship between port and city, Joan Alemany and Rinio Bruttomesso (ed.), 2011, p.32-48). Disponivel em: http:// halshs.archives-ouvertes.fr/halshs-00551208. Acesso: 06.fev.2013.

Na década de 1840 , os principais produtos importados eram, na ordem: tecidos, farinha de trigo, vinhos diversos, ferragem e quinquilharias. Ver tabela de "principais artigos importados de paises estrangeiros... 1840- 1849". In:

Documentos estatísticos sobre o commercio do Imperio do Brasil nos anos de 1845 a 1849. Rio de Janeiro: Typographia Nacional: 1853. p.13. Quinquilharia tem aqui provavelmente seu significado original, segundo o dicionário Houaiss: comércio, mercadoria de quinquilheiro, derivado de quincaille, conjunto de utensilios de ferro, de couro, de zinco.
A baía

Na novela White-Jacket, publicada por Herman Melville em 1851, o jovem Dom Pedro II, "num barco esplêndido, remado por trinta escravos africanos" $^{3}$, visita uma fragata americana ancorada na baía do Rio de Janeiro. Nela está embarcado White-Jacket, um personagem que é o alter ego do autor. Dentro do navio, outro personagem, um jovem marujo da Nova Inglaterra, comenta jocosamente que Pedro "é nome de João Ninguém no meu país. Eu não daria este nome a um cachorro"4.

Já o prisioneiro e ex-marinheiro George Thompson guardou uma boa figura de Pedro II, a quem viu algumas vezes, por volta de 1860, passeando de carruagem pela cidade, escoltado por trinta cavaleiros. Lembrou-se dele "elegante e bonito [...] o governante mais progressista que o Brasil já tivera"5.

0 que Melville e Thompson têm em comum? 0 escritor e o prisioneiro memorialista foram dois entre os milhares de marinheiros de veleiros americanos $^{6}$ que estiveram na baía do Rio de Janeiro ${ }^{7}$ durante décadas, até meados do século XIX. Eles fizeram parte de um grupo de marinheiros, oficiais, passageiros e trabalhadores que escreveram diários, memórias e até textos de ficção com base nas suas viagens. Os seus escritos têm dimensões individuais, de grupo e internacionais. Eles contribuíram e contribuem não somente para o conhecimento de suas experiências na baía do Rio de Janeiro, mas para registrar o cotidiano de uma grande zona portuária ${ }^{8} \mathrm{e}$ para iluminar encruzilhadas da história marítima internacional.

A partir da abertura dos portos, em 1808, o porto do Rio foi se firmando como uma escala estratégica na maior parte das rotas maritimas do mundo de então. Cidade portuária ${ }^{9}$, além de sede do governo do Império português e depois capital do Império do Brasil, o Rio concentrava o escoamento do café, o principal produto brasileiro de exportação, e tornou-se um mercado de consumo tanto de mercadorias produzidas no Império como no exterior. ${ }^{10}$

As embarcações de longo curso ainda eram majoritariamente impulsionadas por ventos e correntes do Atlântico Sul. Assim, navios que iam do Havre para China, de Nápoles para Montevidéu, de Liverpool para Sidney, que voltavam do Pacífico para Nantucket, ou singravam em viagens de circum-navegação pelo globo, com frequência baixavam âncora no Rio. Last but not least, a baía carioca formava um ancoradouro ideal para qualquer quantidade de embarcações, e a cidade comerciava todos os tipos de artigos que um navio carecia.

Mesmo antes de 1808, graças à sua posição estratégica nas rotas de longo curso, o Rio poderia ter abrigado muito mais navios, não fossem as restrições da administração colonial. Se Lisboa proibia o comércio direto com outros países, ainda assim as autoridades coloniais permitiam a ancoragem vigiada de navios estrangeiros que precisassem de água, conserto e mantimentos. Corcino Medeiro dos Santos listou, entre 1791 e 1805, a presença de uma média anual de trinta navios estrangeiros no porto do Rio. A maioria, cerca de $60 \%$, era de bandeira inglesa, seguidos por $25 \%$ de pavilhão espanhol e 12\% (52 navios) de bandeira americana. ${ }^{11}$

0 registro inaugural sobre a baía foi feito em $1^{\circ}$ de janeiro de 1502 , quando o capitão lusitano André Gonçalves a chamou de Rio de Janeiro nome devido, talvez, a uma forte correnteza que acontecia em sua estreita entrada. ${ }^{12}$ Dali em diante, milhares de pessoas anotaram o impacto que a paisagem Ihes provocava. ${ }^{13}$ Ao longo do tempo, o que entusiasmava os viajantes e marítimos era primeiro a beleza natural da baía e sua capacida- 
Tabela XXVI: Procedência dos navios estrangeiros que abrigaram no porto do Rio de Janeiro entre 1791 e 1806. SANTOS, Corcino Medeiros dos. 0 Rio de Janeiro e a conjuntura atlântica. Rio de Janeiro: Expressão e Cultura, 1993. p.213-214.

12

SEDREZ, Lise Fernanda. The 'Bay of All Beauties': Nature and State in Guanabara Bay, Rio de Janeiro, Brazil, 1875-1975. Tese (Doutorado em História). Departamento de História, Stanford University, Stanford, 2005. p.45.

13

Já em 1881, Augusto Fausto Souza fez uma compilação de vários viajantes que visitaram a baía do Rio de Janeiro. SOUZA, Augusto Fausto. A baía do Rio de Janeiro. Revista do Instituto Histórico-Geográfico Brasileiro, t.44, n.63,1881. p.35-70.

14

SEDREZ, Lise Fernanda. Op. Cit., p.32.

15

lbidem, p.39.

16

Utilizo esta expressão como Luciana de Lima Martins, segundo citação do livro Performance de Greg Denning: "era uma época de teatralidade intensiva do civilizado para o nativo, mas sobretudo de teatralidade ainda mais intensa do civilizado em relação a seus pares". Citado em MARTINS, Luciana de Lima. O Rio de Janeiro dos viajantes: 0 olhar britânico (1800-1850). Rio de Janeiro: Jorge Zahar Editor, 2001. p.22.

17

WARD, Kerry. "Tavern of the Seas?" The Cape of Good Hope as an oceanic crossroads during the seventeenth and eighteenth centuries. In: BENTLEY, Jerry H. e outros (ed). Seascapes: Maritime histories, littoral cultures, and transoceanic exchanges. Honolulu: University of Hawai, I Press, 2007. p.146.

18

Ibidem. de portuária, e só depois a cidade e sua sociedade. Muitos afirmaram que a baía do Rio era mais bonita e portentosa que as de Nápoles e Constantinopla, e que não existia porto mais seguro.

Lise Sedrez sintetizou bem as várias camadas que o nome Rio de Janeiro continha e contém: "Baía, província e cidade compartilharam o nome de um rio inexistente. [...] Ainda assim estes diversos espaços produzidos compartilharam não apenas um nome, mas um lugar: as águas, as margens e ecossistema da Baía de Guanabara"14. Espaço a um só tempo, físico, político, nacional, internacional, "a baía era uma arena para trocas de sinais e significados, entre a cidade e seus visitantes, as duas partes fazendo o meIhor para impressionar os representantes de cada sociedade" ${ }^{15}$. Sua extensão e a presença de navios de todos calados e bandeiras evocaram metáforas universalistas. Assim, a partir principalmente de 1808, a baía torna-se uma zona franca cultural, Theatrum Mund $i^{16}$ cuja paisagem tropical servia de palco para que mastros e gentes do mundo todo contracenassem.

Se há um almirante francês no convés, o navio americano ao lado o cumprimenta com doze salvas. Se o é dia de Nossa Senhora, todos a saúdam. Se o imperador passeia pelas águas da baía, 21 tiros de artilharia são disparados de cada navio. Foi assim, com muita pólvora seca, que se estreitaram relações diplomáticas, mencionadas em diversos diários de marítimos.

Centenas de milhares de pessoas passavam horas, dias ou semanas na baía do Rio sem desembarcar ou permaneciam a maior parte da estadia dentro de seus navios onde sofriam e se divertiam, porque o espaço flutuante e fragmentado tinha um cotidiano agitado. Tripulações visitavam-se umas às outras, trocavam livros, frequentavam cerimônias religiosas em outros navios, promoviam festas e compravam quitutes da terra nos botes de quitanda. Os que desembarcavam frequentavam os bairros centrais, e deixaram testemunhos do burburinho carioca. Outros visitavam sítios, florestas e praias mais distantes. Os encontros e trocas - culturais, econômicas e existenciais - que ocorreram na grande zona portuária são incontáveis, e ela pode ser considerada como um dos espaços humanos mais internacionalizados e ricos do período.

0 Rio de Janeiro, como a cidade do Cabo, era uma "cidade encruziIhada"17. Kerry Ward, em seu estudo sobre o Cabo entre os séculos XVIII e XIX, atenta para a população flutuante de marinheiros, soldados e escravos. Mesmo que vivessem no porto sul-africano por curtos períodos, sua presença era contínua e influenciava o cotidiano da cidade..$^{18}$ Os portos do Rio, Valparaiso, Callao e da Cidade do Cabo eram alguns dos principais que integravam o circuito internacional marítimo, no qual os trabalhadores mudavam permanentemente de navios e destinos. Podiam seguir para Austrália, a China, voltar para casa, ou rumar para o Mar Mediterrâneo. 0 caráter global de destinos, escalas e origens aparece em boa parte dos relatos dos marítimos. Tratarei de suas permanências no Rio de Janeiro, mas todos eles estiveram em tantas outras cidades, costas e oceanos, que seus relatos variam de tamanho, dependendo do tempo de estadia ou intensidade de experiência.

Estados Unidos - Império do Brasil: café, farinha, navios e escravos A chegada maciça dos americanos foi uma grande novidade da primeira metade do século XIX no Brasil. Com uma florescente indústria naval, anterior mesmo à sua independência, eles estavam navegando em todos os mares durante 0 século XIX. Já em 1826 os americanos copiaram os ingleses e 
19

HOWARTH, Stephen. To shining sea. A history of the United States Navy 1775-1998. Norman: University of Oklahoma Press, 1999. p.134.

20

Citado em: HOWARTH, Stephen. Op. Cit, p.134.

21

MARTINS, Luciana de Lima. Op. Cit., p.71.

22

CLARK, Joseph G. Lights and shadows of sailor life, as exemplified in fifteen years'experience, including the more thrilling events of the U.S.

Exploring Expedition. Boston: Benjamin B.Mussey \& Co, 1848. p.25-26. Union Jack, uma das denominações da bandeira da Grã-Bretanha.

23

JUNQUEIRA, Mary. Ciência, técnica e as expedições da marinha de guerra americana, U.S Navy, em direção à América Latina (1838-1901). Varia História, Belo Horizonte, v.23, n.38, p.334349, jul-dez/2007

24

Canção ou Shantie Ye Parliament of England. In: SILVERMAN, Jerry. New York sings: 400 years of the Empire State in song. New York: Excelsior Editions, 2009. p.37.

25

HAMOND, Graham E. Os diários do almirante G.E.Hamond. Rio de Janeiro: Editora JB, 1984 p.120.

26

"Esses marinheiros são tipos realmente extraordinários. É impossivel estar em melhores condições do que neste navio, onde não são impedidos de ir à terra nas ocasiões próprias. Mas é o espirito errante que prevalece e, geralmente, encontram modos de se colocar nos navios americanos". HAMOND, Graham E. Op. Cit., p.93.

27

GILE, Paul. "Free trade and sailor's rights": The rhetoric of the war of 1812. Journal of the early republic, v.30, n.1, p.10, spring/2010.

28

Na minha tese de doutorado, trato americanos e ingleses como anglófonos devido à intensa presença de ambos na Armada do Brasil, e à dificuldade de diferenciá-los pela similaridade dos nomes. Apesar de haver rivalidade e diferenças, lingua, a religiosidade, a literalidade, a experiência marítima dos dois povos permite, muitas vezes, agrupá-los como tal. JEHA, Silvana Cassab. $A$ galera heterogênea, marinheiros e recrutas $d a$ Armada Nacional e Imperial do Brasil, c. 1822-c. 1854. Tese (Doutorado em História). Departamento de História, Pontifícia Universidade Católica do Rio de Janeiro, Rio de Janeiro, 2011. p.75-78.

29

Ver: Coleção de mapas estatísticos do comércio e navegação do Império do Brasil. Rio de Janeiro: Typographia Nacional: 1841-1849, vários volumes.

30

Estes dados são da década de 1840. Ver: Coleção de mapas estatísticos do comércio e navegação... 0p. Cit, p.841-1849, vários volumes. instituíram uma estação naval, chamada Brazil Station ou Brazil Squadron, nas águas da baía do Rio para atender e proteger os navios de comércio e de guerra na região sul-americana. ${ }^{19}$ Naquele ano, John Quincy Adams, presidente dos Estados Unidos, declarou no Congresso americano: "Era destino e dever destes Estados confederados tornar-se com o passar do tempo, e sem modéstia de avanço, uma grande potência naval"20. A estação foi duradoura e décadas mais tarde passou a chamar-se Latin American Station. A Inglaterra possuía a sua estação desde 1808, quando o Rio de Janeiro tornou-se a sede do Quartel General da base naval da Marinha Real Britânica na América do Sul. ${ }^{21}$

Um símbolo desse "encalço" aos ingleses, dessa vocação imperial, foi o hasteamento da bandeira americana no cume do Pão de Açúcar, em 1838, por oficiais da U.S. Exploring Expedition. Segundo um marinheiro da expedição, os ingleses já teriam feito o mesmo com a Union Jack. ${ }^{22}$ Para Mary Junqueira, o primeiro objetivo da expedição era "o mapeamento de costas e ilhas e a identificação de portos seguros, com o intuito de assegurar a navegação dos veleiros comerciais americanos." A autora aponta para outro projeto não mencionado nas instruções oficiais da expedição: "0 governo daquele país já procurava fincar as suas bandeiras no mundo, que então era disputado pelas potências europeias".23

Uma canção nacionalista que narra os feitos marítimos dos americanos no século XIX menciona um navio que ficou na Estação Brasil na década de 1840: "O Congress [fragata] na costa do Brasil, seu comércio [britânico] vai incomodar"24. Já na década de 1830, o inglês Graham Eden Hamond, almirante-em-chefe da estação naval britânica na baía, não escondeu seu incômodo: afirmou que a enseada do Flamengo já poderia ser chamada de embaixada americana no Rio de Janeiro..$^{25} 0$ almirante ainda reclamou que o destino dos desertores dos navios ingleses era costumeiramente os navios americanos. ${ }^{26} \mathrm{Na}$ primeira metade do XIX, os marinheiros ganhavam mais e eram submetidos a uma disciplina menos rigorosa nos navios americanos que na Marinha inglesa. Isto causou um êxodo considerável de britânicos para a Marinha americana, carente de marujos especializados para atender seu contínuo crescimento. Por outro lado, principalmente durante as guerras napoleônicas, os americanos foram recrutados à força para a Marinha Britânica. ${ }^{27}$ Os marujos dos dois países, apesar de terem identidades distintas e até opostas, conviveram em ambas as marinhas e em outras (como a brasileira), constituindo uma cultura marítima com muitas intersecções, uma cultura marítima anglófona. ${ }^{28}$

0 comércio exterior com a Inglaterra foi, por muitas décadas, o maior do Império do Brasil. Os Estados Unidos rivalizaram com a França por um segundo lugar durante os anos que se seguiram a 1840, e na década seguinte o posto foi alcançado com segurança - os Estados Unidos eram o maior comprador do café que saía pelo porto do Rio. ${ }^{29} \mathrm{~A}$ balança comercial era favorável para o Brasil, que vendia, além do café, açúcar e couro, e comprava dos americanos farinha de trigo, tecido de algodão e óleo de peixe (baleia). ${ }^{30} 0$ frete de importação e exportação era feito basicamente pelos próprios americanos. 0 Brasil tinha pouca expressividade na navegação de longo curso. 0 pais era também um grande comprador dos navios mercantes e militares dos Estados Unidos, mercadoria que não entrava na lista de bens importados da alfândega nacional. Portanto, frete, indústria naval e envolvimento no tráfico de escravos podem ter revertido o desequilíbrio da balança comercial. Segundo Rafael Marquese, na década de 1840, 
MARQUESE, Rafael. Estados Unidos, segunda escravidão e a economia cafeeira do Império do Brasil. Almanack, Guarulhos, n.05, p.51-60, p.56, $1^{\circ}$ semestre de 2013.

32

Sobre este tema ver CARVALHO, Marcus. 0 desembarque nas praias: o funcionamento do tráfico de escravos depois de 1831. Revista de História. São Paulo, n.167, p.223-260, jul/dez 2012

33

BARRA, Ezekiel I. A tale of two oceans: An account of a voyage from Philadelphia to San Francisco around Cape Horn, years 1849-50. San Francisco, 1893. p.89.

34

Ver sobre o envolvimento dos americanos no tráfico ilegal de escravos: HOWARD, Warren S. American slavers and the federal law 1837-1862. Berkeley/Los Angeles: University of California Press, 1963; GRADEN, Dale T. 0 envolvimento dos Estados Unidos no comércio transatlântico de escravos para o Brasil, 1840-1858. Afro-Ásia, Salvador, n.35, p.9-35, 2007; HORNE, Gerald. 0 sul mais distante. Os Estados Unidos, o Brasil e o tráfico de escravos africanos. São Paulo: Companhia das Letras, 2010. ANDERSON, Eric. Yankee Blackbirds: Northern Entrepreneurs and the illegal international slave trade, 1815-1865. Dissertação (Mestrado em História). Universidade de Idaho, Departamento de História, 1999.

35

MARQUESE, Rafael de Bivar. Op. Cit.

36

Ofício do Consul do Rio de Janeiro Gorham Parks para o Ministro Plenipotenciário dos Estados Unidos no Rio de Janeiro David Tod. In: Message of the president of the United States communicating in compliance with a resolution of the Senate, a report of the Secretay of State, with documents relating to the African slave trade. 31st Congress, 2nd session, December, 18,1850. Este ofício foi incluído num dossiê preparado pelo Secretário de Estado dos Estados Unidos, apresentado ao Senado, sobre envolvimento dos norte-americanos no tráfico de escravos africanos para o Brasil.

37

No banco de dados Transatlanticslave trade, são listados cerca de 60 navios norte-americanos relacionados ao tráfico para o Brasil na década de 1840. Finalmente, segundo Eric Anderson, pelo menos 430 navios norte-americanos teriam feito 545 viagens escravistas principalmente para 0 Brasil e Cuba entre 1815 e 1850.

38

lbidem, p.34
Maxwell,Wright \& Co, ao lado de outras firmas norte-americanas estabelecidas no Rio de Janeiro, logrou articular diretamente a importação da farinha de trigo à exportação de café. Essas companhias criaram um circuito comercial perfeito, no qual as barcas que traziam farinha da Virginia e de Maryland retornavam, para os Estados Unidos, com café brasileiro. ${ }^{31}$

Bandeiras de navios aportados no Rio de Janeiro, 1852-1860

\begin{tabular}{lccccccccc}
\hline EUA & Inglaterra & Portugal & $\begin{array}{c}\text { Cidades } \\
\text { hanseat. }\end{array}$ & França & Espanha & Dinam. & Suécia & Outros & Total \\
\hline 2325 & 1645 & 1007 & 901 & 607 & 582 & 570 & 559 & 692 & 8888 \\
\hline
\end{tabular}

Fonte: Relatório apresentado à Assembléia Geral Legislativa,[...] pelo Ministro e Secretário de Estado da repartição dos negócios da Marinha. Volumes de 1852 a 1860.

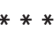

Após 1831, apesar da maior parte do desembarque do tráfico ilegal de escravos ocorrer em portos menores, a baía foi cenário do comércio negreiro, tanto de navios que partiram para a África, quanto da chegada dos apresados pelos ingleses. ${ }^{32}$ Boa parte dos marujos comenta a chegada de navios capturados. Mesmo assim, Ezekiel Barra registrou sem espanto, em 1849, que nas imediações da Praia Grande (atual Niterói) "escunas negreiras construídas em Baltimore para este fim, desembarcam suas cargas de escravos no escuro da noite para os fazendeiros de café" 33 .

Os traficantes brasileiros e portugueses compravam navios americanos ou se associavam com seus donos. ${ }^{34}$ Maxwell \&t Wright, firma profundamente envolvida com o comércio de farinha e café entre os Estados Unidos e Brasil, vendeu vários vasos fabricados em Baltimore, que foram usados no tráfico, ${ }^{35}$ muitos com uma parte da tripulação americana.

Em janeiro de 1850, Gordon Parks, cônsul dos Estados Unidos no Rio, redigiu um relatório sobre o envolvimento dos americanos no comércio ilegal de escravos. As duas primeiras frases do relatório são curtas e grossas: "Cinquenta mil africanos são importados anualmente para o Brasil e vendidos como escravos. Acredito que a metade deste número é introduzida por meio das facilidades direta ou indiretamente proporcionadas pela bandeira americana" ${ }^{36}$. Para respaldar sua denúncia, Parks listou quase cem navios de bandeira americana que, entre 1844 e 1849, partiram do Rio de Janeiro para África, continente com o qual os Estados Unidos não mantinham relações comerciais oficiais. ${ }^{37} 0$ cônsul defendeu no relatório um combate mais ostensivo à participação americana no tráfico ilegal de escravos africanos para o Brasil, criticando a tática da estação naval americana e elogiando a britânica:

Sei que as autoridades navais pensam que é necessário haver um navio grande na costa do Brasil, especialmente na baía do Rio, para impressionar o Governo e a população do Brasil com a nossa grandeza e importância nacional. [...] Os brasileiros não são bárbaros, sendo sua elite e governo bem informados, são intelectuais que não precisam de navios pomposos para saber da nossa posição na família das nações. A Grã-Bretanha tem uma estratégia melhor. Ela não tem grandes navios inúteis e ociosos, todas suas embarcações são ativas, vigilantes. 0 dinheiro gasto em manter um navio de primeira linha, ou fragata, seria melhor empregado em equipar pequenos navios, o que colaboraria mais com a supressão do tráfico de escravos. ${ }^{38}$ 
39

HAMOND, Graham E. Op. Cit., p.89.

40

WILKES, Charles. Narrative of the United States exploring expedition during the years 1838, 1839, $1840,1841,1842$. Vol. 1. Philadelphia: Lea \& Blanchard, 1845. p.55.

41

Ibidem, p.54.

42

SCHULTZ, Charles R. Forty-niners round the Horn. Columbia: University of South Carolina Press, 1999.

43

BARRA, Ezekiel I. Op. Cit.

44

Jornal do Commercio. Rio de Janeiro, 11 de março de 1849.
Os americanos não estavam na baía para suprimir o tráfico de escravos, e sim para apoiar o comércio americano com o Brasil e a América do Sul, além de exercer seu poder simbólico no continente americano. Neste sentido, grandes fragatas da Estação Naval atendiam os objetivos dos Estados Unidos, e não atrapalharam os negociantes americanos envolvidos no tráfico.

As "fofocas" sobre o envolvimento dos americanos no tráfico de escravos circulavam na baía, já que tantos navios americanos, com ou sem bandeira deste pais, partiram dali em direção à África. Em 1834, o almirante inglês Graham Hamond comentou em seu diário a venda na baía do brigue americano Commodore, renomeado Comodoro, a um português: "sem dúvida uma venda fictícia. 0 navio partiu para Moçambique, de onde trará uma carga de escravos para cá. É realmente escandaloso o descaramento com que levam avante esse comércio"39.

Os americanos também criticaram os ingleses. Charles Wilkes, 0 capitão da expedição de circum-navegação U.S. Exploring, admirou-se do mau estado dos quinhentos africanos de dois navios negreiros apreendidos e sob a guarda da esquadra inglesa na baia: "É difícil imaginar criaturas mais emaciadas, nuas e de aparência bestial, e é surpreendente que eles sejam mantidos confinados por aqueles que assumiram garantir sua liberdade e melhorar sua condição" ${ }^{40}$. 0 americano observara que "0 grande e distintivo caráter do Rio são seus escravos e a escravidão" ${ }^{41}$. Os sofrimentos impingidos aos africanos tinha um caráter internacional, e a baía do Rio de Janeiro era um cenário onde interesses e ações de todos os envolvidos convergiam.

A partir de 1849, durante a corrida do ouro para a Califórnia, centenas de embarcações americanas usaram o porto do Rio como escala. 0 historiador Charles R. Schultz catalogou cerca de cem diários de passageiros e marítimos que participaram, entre o fim de 1849 e o início de 1850, da exploração do ouro californiano, muitos dos quais desembarcaram no Rio. ${ }^{42}$ 0 marinheiro Ezekiel Barra foi um deles. Sua estadia foi de um mês na cidade. Participou de um banquete de ano novo no Hotel Lisboa. Envolveu-se numa briga entre um marinheiro e o capitão do navio que terminou com este último ferido. 0 agressor foi preso na Casa de Detenção, e Ezekiel Barra empenhou-se em tirá-lo das grades com a ajuda de um advogado holandês que morava na cidade. A história se desenrola por várias páginas, nos dando a oportunidade de entrarmos na cadeia, na casa do advogado e no hotel. ${ }^{43}$

Em 11 de março de 1849, o Jornal do Commercio noticiou a presença, em uma única semana, de dezoito navios americanos ancorados no Rio cujo rumo era a Califórnia. Anunciava também que a yellow fever, um dos apelidos da corrida do ouro de 1849-1852, contaminava os brasileiros, que estariam organizando excursões ao novo Eldorado. ${ }^{44} 0$ jornalista não sabia que prenunciava outra epidemia homônima, que se alastraria no Rio em fins daquele ano, matando milhares de pessoas.

$\mathrm{Na}$ década de 1850, a maior parte dos navios ancorados no porto tinha bandeira americana, superando inclusive o número de navios ingleses. Em 1852, James Fletcher, missionário junto a marinheiros, explicou que no porto do Rio havia navios americanos em quatro áreas de ancoragem. 
45

FLETCHER, James C. Brazil chaplaincy. Rio de Janeiro, May 11, 1852. To the secretaries of the American Seamen's Friend society. The sailor's magazine, New York: American Seamen's friend society, v.XXV, n.3, p.81, nov/1852.

46

Os oficiais portugueses, franceses, holandeses, germânicos, entre outros, publicaram memórias; quanto aos marinheiros comuns destes paises, não tenho conhecimento de um conjunto tão extenso quanto dos anglófonos.

47

BLUM, Hester. The View from the Masthead: Maritime Imagination and Antebellum American Sea Narratives. The University of North Caroline Press, 2008. p.266. Sobre literalidade e os hábitos de leituras dos marujos ver a seção "Literacy asea".

48

BOLSTER, W. Jeffrey. Black Jacks: Afro-american seamen in the age of sail. Cambridge: Harvard University Press, 1997. p.37.

49

Ver: LINENBAUGH, Peter; REDIKER, Marcus. A hidra de muitas cabeças: marinheiros, escravos, plebeus e a história oculta do Atlântico revolucionário. São Paulo: Companhia das Letras, 2008.

50

BENJAMIN, Walter. 0 narrador: observações sobre a obra de Nikolai Leskow. In: Textos escolhidos: Benjamin, Horkheimer, Adorno, Habermas. São Paulo: Abril Cultural, 1980. p.60.
Assim, os navios em escala, os que se destinavam para Califórnia, permaneciam próximos à saída da baía, de uma a duas milhas da terra. Os navios militares ficavam na área seguinte. Os que descarregavam, fundeavam nas proximidades da cidade. E os que já haviam descarregado ficavam numa outra área. Nos cálculos de Fletcher e do cônsul americano, havia de dez a quinze navios americanos toda semana na baía, o que contabilizaria cerca de 4200 homens por ano, só dos navios mercantes. ${ }^{45}$ Se a média de homens num navio mercante era quinze, nos navios de guerra a tripulação era sempre de mais de uma centena, podendo chegar a mil pessoas numa única embarcação.

Enfim, comércio de farinha e café, época de ouro dos baleeiros, estação naval americana, envolvimento de navios americanos no tráfico de escravos e corrida de ouro para Califórnia trouxeram milhares de marítimos americanos para o Rio de Janeiro. Dentre eles, centenas deixaram registros sobre esta passagem.

\section{A narrativa marítima americana e o Rio de Janeiro}

No tempo dos veleiros, apesar de trabalharem duro a maior parte do tempo, os marinheiros desfrutavam de horas sem ter o que fazer, devido às calmarias e longas paradas nos portos. Uma parte razoável dentre os anglófonos ${ }^{46}$ dedicava-se à leitura e à escrita. Estima-se que de 80 a 90\% dos marinheiros americanos sabiam ler e escrever. ${ }^{47}$ Este era um traço da cultura de paises protestantes, religião que incentiva a literacia para que não haja intermediários entre a Bíblia e o fiel. Tal aspecto, absorvido pela cultura maritima anglófona, nos legou centenas de livros de memórias de marinheiros e um sem-número de diários manuscritos, dos quais uma quantidade razoável foi guardada nos arquivos americanos e britânicos. Foram os britânicos que primeiro começaram a publicar livros com relatos de viagem de marítimos, mas os americanos logo se equipararam e provavelmente os superaram. Antes mesmo de 1800, as primeiras autobiografias de afro-americanos foram escritas por marinheiros. ${ }^{48}$

A partir desses diários e memórias - muitas vezes complementados por consultas e cópias bibliográficas, conforme vários estudos demonstraram - muitos maritimos publicaram seus escritos e constituíram a chamada sea narrative (narrativa ou literatura marítima), cultura muito em voga na Inglaterra e nos Estados Unidos ao longo do século XIX. Fizeram parte da sea narrative grandes nomes da literatura americana: James Fenimore Cooper, autor de 0 Último dos Moicanos e mais de dez novelas maritimas; Richard Francis Dana, que em 1840 publicou o clássico Two years before the Mast e fez sucesso de crítica e público nos Estados Unidos e na Europa; e Herman Melville, escritor de diversos livros passados no mar e de um dos maiores romances do século XIX, Moby Dick.

Estudos históricos sobre marítimos são mais comuns em paises do Atlântico Norte. Seus autores tem sido qualificados como trabalhadores e narradores admiráveis na história global. ${ }^{49}$ Para Walter Benjamin, eles são, ao lado dos lavradores, representantes arcaicos dos narradores. ${ }^{50} 0$ crítico literário Hester Blum analisou diversos livros da sea narrative no antebellum, o período da história americana que se inicia com a Revolução e termina na Guerra Civil. Ele identifica o que chamou de sea eye, o olhar marítimo, que, conforme diz, "reflete tanto o seu conhecimento técnico especializado quanto a absorção de uma cultura antebellum mais ampla, por meio da leitura e produção de textos literários". 0 olhar maritimo seria um 
FRANÇA, Jean Marcel Carvalho; RAMINELLI, Ronald. Andanças pelo Brasil colonial. Catálogo comentado 1503-1808. São Paulo: Editora Unesp, 2009. p.21.

54

MORRELL, Capt. Benjamin. A narrative of four voyages... New York: J\&J Harper, 1832. p.37-38.

55

Os botocudos e kaingangs foram os últimos alvos das guerras justas coloniais contra os indios. Logo que D. João chegou ao Brasil declarou a chamada então "guerra justa" contra eles, que acabou oficialmente em 1831. 0 argumento, em geral, era baseado na "ferocidade" dos índios. Ver a este respeito a minha dissertação de mestrado: JEHA, Silvana Cassab. 0 padre, o militar e os índios: Chagas Lima e Guido Marlière: civilizadores de botocudos e kaingangs nos sertões de Minas Gerais e São Paulo, século XIX. Dissertação (Mestrado em História). Universidade Federal Fluminense, Departamento de História, Rio de Janeiro, 2005.

56

HOLBROOK, Samuel. Threescore years: An autobiography containing incidents of voyages and travels including six years in a man-of-war.. Boston: James French \& C., 1857. p.312-314. "tipo de visão que abarca trabalho e contemplação"51. 0 trabalho, a experiência no mar e nos portos, somados às leituras, constituiriam a substância literária dos autores.

Os escritos de marítimos sobre o Brasil formam um coletivo de testemunhos que, para além das características literárias desiguais, ligariam a história da cidade à história marítima internacional. 0 conjunto de escritos marítimos recria a história cotidiana das cidades portuárias, a vida costeira e marítima, e demonstra como o Brasil participava, na prática e no sangue dos homens, do capitalismo mundial.

Herdeiros e leitores da tradição europeia de literatura de viagem, os marítimos americanos a recriaram num contexto econômico e cultural novo e diverso. As listas de livros das bibliotecas dos navios americanos do século XIX relacionam principalmente narrativas maritimas, fiç̧ão europeia e americana, livros de viagem, de aventuras e religiosos. ${ }^{52}$ Os marítimos reproduziram consideravelmente a visão detratora que os viajantes mais eruditos explicitavam em suas observações tanto sobre a ex-colônia, quanto sobre o novo Império. Segundo Ronald Raminelli e Jean Marcel França: "Em linhas muito gerais não seria equivocado dizer que as descrições do Brasil contidas em tais escritos sustentaram-se sobre a oposição entre uma terra rica, pródiga e bela e um povo, desde muito cedo, corrompido, indolente, inculto, enfim, indigno de ser o senhor de uma terra tão auspiciosa"53.

Esta concepção é corrente em escritos de diversos marítimos, tanto oficiais quanto marujos. Em 7 de setembro de 1822, enquanto o seu navio partia, Benjamin Morrell, capitão de baleeiro, refletiu sobre "este país adorável" que estava se tornando independente:

Olhando para trás, enquanto aquele lindo cenário esvanecia, eu não podia deixar de lamentar que a moral não correspondesse ao aspecto físico deste país adorável. Torres e cúpulas, [...], igrejas, conventos e villas e um labirinto de mastros encimados por bandeiras de quase todas as nações desapareciam com a distância. ${ }^{54}$

0 navio de guerra americano onde estava embarcado o jovem carpinteiro Samuel F. Holbrook ancorou por alguns dias, em março de 1821, no Rio de Janeiro. Tempo suficiente para vivenciar três experiências exóticas e confirmar os preconceitos sobre as etnias dos habitantes locais. Num passeio de um dia na baía, encontrou indios botocudos capturados nas chamadas "guerras justas" 55 e mantidos numa ilha: "as mulheres velhas eram as criaturas humanas mais horriveis que eu jamais vira". Ele presenciou um desembarque de escravos: "se eu ainda tinha alguma dúvida que os negros pertencessem a nossa raça, ela acabara naquele momento". E finalmente, para contrastar com essa gente amedrontadora, descreveu sua redenção em meio à natureza dadivosa: "apenas aquele que pode colher uma laranja de uma árvore em seu solo nativo pode apreciar a luxúria e a delícia dessa fruta"56.

0 desprezo dos maritimos americanos pelos brasileiros era parte de uma perspectiva mais abrangente e específica: contra latinos e católicos e acrescida do orgulho nacional. Além de protestantes, os americanos se viam como o povo eleito, a nova nação promissora. Isto fica bem claro na descrição das tripulações feitas por George Thompson, que apesar de forada-lei assumido e de ter ficado cerca de trinta anos preso, era um patriota. Ele gostava de ir ao cais militar do Rio para ver "as peculiaridades das diferentes nações". Nas suas palavras, "os americanos eram os mais inteli- 
57

THOMPSON, George (pseud.). Op. Cit., p.87-88.

58

HAZEN, Jacob. Five years before the mast or Life in the forecastle, aboard of a whaler and man-of war. Philadelphia: G.G. Evans, 1859. p.153.

59

GLENN, Myra C. Jack Tar'story: the autobiographies and memoirs of sailors in antebellum America. New York: Cambridge University Press, 2010. p.103.

60

AMES, Nathaniel. A mariner's sketches, Providence (EUA): Cory, Marshall \& Hammond, 1830. p.196.

61

Ibidem, p.192.

62

Ibidem.

63

BUNNEL, David C. The travels and adventures of David C. Bunnell during twenty three years of a sea-faring life; containing an accurate account of the battle on lake Erie,(..); together with tem years service in the navy of the United States also - service among the greeks, imprisonment among the turks, etc. etc. Palmyra, NY: J. H. Bortles, 1831. p.98.

64

Ibidem, p.147-148. gentes, elegantes e altivos". Os ingleses, "desarrumados, não aparentavam esperteza e boa disposição [...] "Os italianos, espanhóis, franceses e brasileiros eram um bando sujo de pés descalços, provavelmente nenhum entre dez deles sabia ler ou escrever".57

Em 1838, o marujo americano Jacob Hazen desertou de um baleeiro no Rio de Janeiro e se empregou como sapateiro na loja de um conterrâneo, além de se engajar temporariamente como marinheiro de cabotagem num navio brasileiro. Numa madrugada, foi recrutado à força para a Armada do Brasil e permaneceu por três semanas na nau Pedro I, ancorada na baía. Ele descreveu assim a tripulação: "os homens eram pretos e sombrios [...] e mesmo o comandante, com sua face preta e peluda [...] parecia um orangotango".58

0 marinheiro Nathaniel Ames, que participou de guerras de independência na América Latina, "expressou várias emoções em sua narrativa nacionalismo estridente, raiva contra aqueles que insultassem ou ameaçassem a sua nação ou navio, hostilidade contra estrangeiros e orgulho do marinheiro americano"59. Escreveu frases como: "Sempre achei que a única maneira de lidar com um espanhol, um português ou italiano [...] era nocauteá- $\operatorname{los}^{160}$. Em 1824, os oficiais da fragata United States, onde estava embarcado, resgataram um marinheiro americano forçado a servir. Ele seria "um entre muitos", pois o Almirante Cochrane estava "recrutando cada homem que ele conseguisse colocar as mãos" 61 . Tal situação, entre outras que presenciou na costa sul-americana do Pacífico, o convenceu de que "todos esses governos sul-americanos merecem uma boa surra (sound trashing) a cada ano, para entenderem a diferença entre meum e tuum e outros assuntos concernentes à lei civil e às leis das nações"62.

Esta literatura maritima pode ser dividida em dois formatos. 0 maior, que é uma combinação de autobiografia e literatura de viagem, e um menor, que é o da ficção, também inspirado em experiências e/ou diários, que explora livremente os símbolos e alegorias das viagens. Vejamos dois exemplos destes dois tipos de abordagem.

0 marujo David Bunnel esteve na baía do Rio de Janeiro por três vezes, nunca conheceu a cidade a sua margem, mas passou por experiências intensas nas suas águas. Bunnel procurou relatar detalhes dos 23 anos de sua vida no mar (ainda que erre bastante as datas). Na década de 1810, embarcado a força num navio de guerra britânico durante uma escala no Rio, escreveu ao cônsul americano a fim de obter sua liberdade. Surpreendido em flagrante, recebeu uma dúzia de chicotadas, e lhe ameaçaram com mais três dúzias, caso tentasse de novo. ${ }^{63}$ Sua estadia seria bem mais agradável, anos depois, quando voltou a bordo de um navio da Marinha americana, da onde assistiu, em 1818, a coroação de Dom João como soberano do Reino Unido de Portugal, Brasil e Algarve: "Foi o mais lindo espetáculo que se possa imaginar de dia e tão pitoresco à noite, a cidade completamente iluminada estava além da imaginação. Havia mais de mil salvas diária, durante três dias"64. Desse modo, o Rio, decorado festivamente por Jean Baptiste Debret, artista da comissão francesa, convertera-se em palco para os cariocas e os tripulantes dos navios estrangeiros. A coroação do rei foi também uma cerimônia encenada para o ambiente internacional da baía, e muitos devem ter narrado o que viram por todas as partes do globo.

Bunnel voltaria uma terceira vez ao Rio, depois de uma aventura terrivel nas margens do Rio da Prata, onde o navio português que estava embarcado naufragou. Foi um dos poucos que se salvou. Com mais uns 
65

A fragata Isabel, sob comando de Theodoro Beaurepaire, combateu e apresou o corsário Hijo de Julio em 8 de junho de 1827 no Cabo de Santa Maria. DONATO, Hernani. Dicionário das batalhas brasileiras. Dos conflitos com indígenas aos choques da reforma agrária (1996). São Paulo: Ibrasa: 1996. p.224-225.

66

BUNNEL, David C. Op. Cit. Esta trajetória é contada a partir do capítulo XVIII.

67

MELVILLE, Herman. 0p. Cit., p.526-527.

68

Havia cosmoramas em Paris, Londres e Nova York a partir de 1807. ALTICK, Richard D. The shows of London. Harvard University Press: 1978. p.211.

69

MELVILLE, Herman. Op. Cit., p.568. dois companheiros famintos, encontraram indígenas na mata que lhes ajudaram. Chegou a uma baía portuária no atual Uruguai, onde foi recrutado à força pelos oficiais da fragata Isabel, da Marinha brasileira. A fragata se envolveria dias depois numa batalha contra um navio corsário contratado pelos estados do Prata. ${ }^{65}$ Ela seguiu então para o Rio, e David Bunnel foi transferido para o navio depósito Pedro I, onde, segundo o próprio, quase morreu asfixiado. Por fim, ele foi destacado, junto com mais dez americanos, para um navio que tinha a Áustria como destino, numa missão que envolvia o futuro casamento de Pedro I com sua segunda consorte, a princesa Amélia de Leuchtenberg. Bunnel desertou em Livorno, na Itália, da onde continuou seu périplo de retorno aos Estados Unidos. ${ }^{66}$

Herman Melville que esteve no Rio de Janeiro duas vezes por poucos dias, elegeu a baía como cenário para mais de um quarto de sua novela White-Jacket. Suas águas plácidas eram o palco; a cidade, a floresta e as montanhas, o cenário majestoso para descrever a vida do navio de guerra no qual viajara entre 1843 e 1844. 0 escritor desfez o tempo cronológico da viagem para condensá-lo nesse panorama. A forma de anfiteatro já havia sido evocada por diversos viajantes, mas os marujos-escritores transformam o mar em arena. Assim, a paisagem é cenário para uma intensa vida do multi-palco flutuante.

Melville enumera alguns dos passatempos dos marinheiros estacionados na baía: andar no deque de armas admirando trechos do cenário pelas escotilhas é um deles. A paisagem vista através delas torna-se representação:

A diversidade da variada e charmosa paisagem da baía: montanha,vale, pradaria, castelo, torre, bosque, videira, vinha, aqueduto, palácio, praça, ilha, forte - era comparável a entrar num Cosmorama, onde espiamos através das lentes de vez em quando, [...] Estando num navio, o vislumbre de um cacho de uvas, mesmo que à distância, era comparável à degustação de um pernil. ${ }^{67}$

Cosmorama era um local de entretenimento na Europa e nos Estados Unidos. Tratava-se de uma instalação num salão circular, com pinturas de lugares célebres do mundo todo nas paredes, as quais deveriam ser vistas através de engenhocas feitas de lentes convexas, mas também com espeIhos e panos pretos que davam a impressão de "uma realidade separada"68. Melville mescla ficção e realidade, valorizando as experiências sensoriais. As escotilhas convertiam-se em lentes: estar dentro de um navio na baía do Rio era como visitar o Cosmorama da Regent Street em Londres; assim como comer um pernil suculento era equiparável à visão de um belo cacho de uvas.

Melville não escreve necessariamente sobre as suas experiências cotidianas. É no plano simbólico, literário e sensorial que seu texto sobre a baía se envereda. Sua lente literária "cosmorâmica" não pretende apenas transportar o leitor para um espaço, mas também para outros tempos, sendo a baía um cenário perfeito para o Teatrum Mundi, já que todas as nações maritimas têm representantes ali.

Inicialmente, ele avisa que não descreverá as suas maravilhas, mas acaba "tomado por uma inundação de lembranças perfumadas", e escreve o capítulo poético "A baía de todas as belezas", de "ar almiscarado" e cujos "picos cônicos, ao seu redor, queimavam como vastos círios ao nascer e ao por do sol"69 Num tom místico, Melville teatralizou o cenário, recriou pas- 
71

THOMPSON, George (pseud.). Op. Cit., p.85.

72

GIUE, Paul. On the waterfront: maritime workers in New York city in the early republic, 1800 - 1850. New York History, v.77, n.4, p.396-397, october, 1996.

73

BARRA, Ezekiel I. Op. Cit., p.135.

74

MACAULAY, Hastings W. Kathay: a cruise in the China seas. New York: G.P. Putnam \& Co., 1852. p.16. sagens da Bíblia e da história do planeta, diminuindo a presença histórica luso-brasileira e tornando a baía do Rio num palco para o encontro de todas as grandes frotas de todos os cantos do mundo e de todos os tempos:

Rio anfiteátrico! Na sua larga expansão será realizada a ressurreição e o dia do juízo final de todos os navios de guerra do mundo, [...] as naus capitânias dos galeões fenícios de Tiro e Sida; das esquadras anuais do Rei Salomão que viajavam para Ophir... os brigues de guerra, escunas que derrotaram os ingleses no Lago Erie... as canoas dos reis polinésios, Tammahammaha e Pomare - ah! Na baía abundante do Rio, tendo o Comodoro Noé como almirante de todos almirantes, estas naus capitânias navegam em concerto durante o primeiro dilúvio! ${ }^{70}$

\section{De Tântalo a Dionísio: entre o desejo e o prazer}

Quando no Rio, o nova-iorquino George Thompson desertou do navio mercante inglês, no qual embarcara na costa do Peru, e se hospedou na estalagem de Joe Portuguese. Passou ali duas semanas extraordinárias, segundo suas memórias:

\begin{abstract}
Não havia limites na casa: podíamos ter o que quiséssemos, e como estavam felizes os outros hóspedes ao nos encontrar! Todo esse afeto custou para mim e Jimmy várias rodadas de drinques [...] Que mudança de modo de vida! Frutas de todos os tipos por quase nada; camas confortáveis para dormir; comida fresca e vegetais para comer. ${ }^{71}$
\end{abstract}

George e seu amigo gastaram muito dinheiro em pouco tempo. Duas semanas depois, o sonho acabou e precisaram se engajar num navio novamente. Segundo Paul Gilje, o marinheiro beberrão e perdulário é um estereótipo da vida portuária dos marujos. Mas apesar de haver entre eles muitos religiosos, morigerados, politizados, fiéis a familias, tratava-se de uma imagem e uma realidade da maioria dos marinheiros da época dos veleiros. ${ }^{72}$ É claro que não se trata de uma natureza da profissão, mas certamente era resultado de suas precárias condições de trabalho e do ambiente cotidiano de confinamento. Quando desembarcavam, muitos se lançavam intensamente aos prazeres da cidade, durante o pouco tempo que dispunham fora da disciplina rigorosa dos navios, chamado não à toa de liberty, liberdade.

0 marujo Ezekiel Barra passou um mês aportado no Rio quando migrou da costa Oeste americana para a Califórnia. Comeu muitas bananas, laranjas e peixe fresco frito nas barracas da cidade. Numa manhã, por cem réis comprou bananas de uma negra de ganho que the alimentaram por todo o dia. Ele considerava que a "Dama Natureza era pródiga em presentes à gente dessa terra favorecida" e descreveu o mercado da cidade como:

\footnotetext{
uma oferta desconcertante de vegetais e frutas que excediam qualquer coisa que eu imaginara: alcachofras, feijões, pepinos, berinjelas, alface, quiabo, batatas doces, inhames e outros, numerosos demais para listar. Das frutas: bananas, bananas da terra, limões, laranjas, goiabas, romãs, e muitas outras. Aves nas gaiolas; peixes recém-pescados. ${ }^{73}$
}

0 oficial W.H. Macaulay lamentou a impossibilidade de desembarcar no Rio de Janeiro, devido à epidemia de febre amarela: "Ali estávamos, a metros da Ilha das Cobras, com todas as plantas e frutas tropicais quase ao nosso alcance, nos tantalizando com seu perfume. [...] Pensamos no destino de Tântalo, em Prometeu e a rocha, e na expulsão de Adão"74. Na mitologia grega, o rei Tântalo foi castigado com a sede e 
75

GRIMAL, Pierre. Dicionário de mitologia grega e romana. Rio de Janeiro: Editora Bertrand Brasil, s.d. p.428.

76

JOHNSON, Daniel Noble. The journals of Daniel Noble Johnson (1822-1863) United States Navy. Edited by Mendel L. Peterson. Smithsonian Miscellaneous Colletions, v.136, n.2, Washington, Smithsonian Institution, p.95, 1959.

77

NORDHOFF, Charles. Nine years a sailor: Sketches of personal experience in the United States Naval Service, the american and British Merchant marine, and the whaling service. Cincinnat: Moore, Wilstach\& Baldwin, 1866. p.118.

78

Ibidem, p.253.

79

Não sei se este "Portuguese Joe" e o dono da estalagem onde George Thompson se hospedou são as mesmas pessoas. Ele aparecerá novamente, mais adiante, como traficante de aguardente na baía.

80

DEBRET, Jean Baptiste. Voyage pittoresque et historique au Brèsil. Tome II. Paris: Firmin Didot Frères, Imprimeurs de L'Institut de France, 1835. p. 175

81

Sobre a alimentação de marinheiros até o século XVIII, ver RODRIGUES, Jaime "Um sepulcro grande, amplo e fundo: a saúde alimentar no Atlântico, séculos XVI ao XVIII. Revista de História, São Paulo, n.168, p.325-350, $1^{\circ}$ semestre 2013.

82

NORDHOFF, Charles. Op. Cit., p.128-129. a fome eternas. "Mergulhado até o pescoço, não podia beber, porque 0 líquido fugia sempre que tentava mergulhar nele a boca; um ramo carregado de frutos pendia sobre a sua cabeça, mas, se levantava o braço, 0 ramo erguia-se bruscamente e ficava fora do seu alcance" ${ }^{175}$. Um oficial só seria proibido de desembarcar mediante uma epidemia. Em 1842, escrivão do navio Delaware, Daniel Johnson, não foi expulso do paraíso. Ao contrário: foi recebido por uma viúva "linda e hospitaleira" num lugar que os "iniciados" chamavam de Paradise. Em Praia Grande, atual Niterói, depois de cavalgar com um aprendiz do navio, visitou a "famosa pulperia" da viúva Constant, que Ihes serviu refrescos, permitiu que colhessem frutas das árvores generosas da propriedade e ainda os presenteou com um "lindo buquê das flores tropicais mais delicadas".76

Milhares de marinheiros nunca desembarcaram de seus navios, restando de consolo, a paisagem. Em torno de 1845, o marujo Charles Nordhoff e a tripulação de setecentas almas do seu navio de guerra não puderam nem subir à proa quando chegaram à baía. Tiveram de olhar através de escotilha. Nordhoff não achou divertido brincar de Cosmorama como o personagem de Melville: comparou a frustração a olhar pelo buraco da fechadura e, tal qual o oficial Macaulay, ele se sentiu castigado como o rei Tântalo "desejando as maças"77. Quando voltou, anos depois, num navio mercante, também não pôde descer, desta vez pelo medo de ser recrutado pela Marinha do Brasil, "sedenta" de homens. Um camarada seu passou pela experiência e the disse que não a desejava para ninguém. ${ }^{78}$

Apesar de não desembarcar, Nordhoff comprou frutas e outros alimentos no bote de quitanda de Portuguese Joe..$^{79} 0$ marujo dá vida à idilica gravura de Jean Baptiste Debret chamada Vivandier maritime. Nela observa-se o pão, as bananas e laranjas que ele degustou, além de café fumegante. ${ }^{80} 0$ comércio é feito tranquilamente. Já a compra de Nordhoff foi muito mais aventurosa. A descrição desse encontro é dramatizada pela combinação do fastio da comida em conserva do navio com o desejo pelo frescor do desconhecido. Acresce o medo de Portuguese Joe, "o mais famoso dos quitandeiros". Os companheiros, que já haviam aportado no Rio, disseram que ele era matador de marinheiros, e que usava veneno stilleto. Quando os botes chefiados pelo português começaram a rondar o navio, o rapaz de quinze anos, logo após sua primeira travessia transatlântica, cheio de autoconfiança, decidiu-se por ser "o mais ousado de todos os marinheiros", "fiel ao mote cada um por si". Com o dinheiro dentro da boca, ele se arremessou dentro de um dos botes, apanhou quantas laranjas couberam dentro da blusa e carregou cachos de bananas nas duas mãos, além de goiabada embrulhada em folha de bananeira e pão fresco. Pulou de bote em bote até chegar onde previa. Pagou o que adquiriu e subiu feliz no navio onde comeu mais tarde seu "picnic" com um camarada. ${ }^{81}$ Segundo Nordhoff, a goiabada era muito popular entre os marujos, mas ao seu paladar parecia areia com açúcar derretido. 0 que mais Ihe encantou foi a desconhecida banana. Ele descreveu a degustação da iguaria como um acontecimento: "bastou a experiência de deixar uma derreter na boca para garantir que não havia fruta mais deliciosa dentre as frutas tropicais".82

Portuguese Joe também é o nome de um personagem na novela cômica The adventures Harry Franco, pseudônimo do jornalista Charles Briggs, marítimo por alguns anos na década de 1820, quando conheceu a América do Sul. A personagem Harry Franco deserta de seu navio mercante, foge dos agentes recrutadores brasileiros pelas ruas do Rio e pula num bote de 
Como demonstrei na minha tese, centenas ou até milhares de americanos escreveram para - Consulado, reclamando que haviam sido recrutados à força para a Marinha do Brasil. JEHA, Silvana. A galera heterogênea... Op. Cit., capitulo Os estrangeiros, p.45-102.

84

Os marujos e/ou os contrabandistas de cachaça inventaram um tipo de container maleável parecido com uma bexiga para poder esconder bebidas alcoólicas mais facilmente.

85

BRIGGS, Charles. The adventures of Harry Franco: a tale of the great panic. New York: F.Saunders, 1839, vol.01, p.253.

86

JOHNSON, Daniel Noble. Op. Cit., p.94.

87

THOMPSON, George (pseud.). Op. Cit., p.88.

88

NORDHOFF, Charles. Op. Cit., p.137. um navio de guerra americano, onde se alista. ${ }^{83}$ Já embarcado, é escalado para uma missão, junto com outros marujos e dois oficiais, na Hospital Island, dentro da baia, onde os americanos manteriam um armazém. 0 oficial responsável pela expedição, um guarda-marinha, comprou seis bexigas ${ }^{84}$ de aguardente do bote do contrabandista Portuguese Joe e bebe uma inteirinha até cair no chão roncando. 0 outro oficial e alguns marinheiros também bebem e voltam para o navio - onde todos são chicoteados, com exceção do heroico Franco (um dos únicos sóbrios) que escapa do chicote através de mil peripécias. ${ }^{85}$

Em 1843, o capitão do navio Delaware, da estação naval americana, autorizou os marinheiros a tomarem banho de mar na baía, numa tarde quente de fim de outubro. Eles voltaram bêbados. Descobriu-se mais tarde, cerca de 15 litros de aguardente presas às boias, que estavam perto deles enquanto nadavam. ${ }^{86}$

A bebida é um grande tema dos marujos aportados em qualquer porto. Boa parte das narrativas menciona algum contrabando seguido de castigo. A Marinha de guerra americana, e de outras nações como Inglaterra e Brasil, servia diariamente duas rações de grogue. Ração que variava de 100 a $200 \mathrm{ml}$ diárias. Quem não consumisse recebia o valor em dinheiro. A existência ou não desta dose diária, nunca impediu o contrabando no navio e as farras em terra. A ração de grogue foi abolida no Congresso americano em 1862.

A aguardente era contrabandeada nas chamadas bexigas na novela de Charles Biggs, ou peles ("como as usadas para fazer linguiças de Bolonha") nas memórias de George Thompson e Charles Nordhoff. Este último explicou que elas eram feitas de bexiga de boi.

Aqueles que desciam em solo podiam usufruir à vontade da cachaça. Thompson descreveu uma versão falsificada da aguardente: "uma parte de álcool puro, uma parte de água e uma boa porção de creosote resultavam num paladar parecido com a original". Seu amigo Jimmy teve uma intoxicação que o deixou estirado na mesa da estalagem com espasmos e a boca trêmula. ${ }^{87}$ Nordhoff não teve coragem de experimentar o líquido das peles que viu contrabandeadas em seu navio na baía, mas imaginou, pelo cheiro, tratar-se de uma mistura de terebintina, água e um pouquinho da aguardente local. ${ }^{88}$

A deserção pode ser classificada como uma das delícias da baía, para usar uma expressão de Melville. Era uma cultura maritima mundial. 0 melhor lugar para fazê-lo era os grandes portos. 0 enorme número de navios de várias nacionalidades representava um mercado de trabalho razoável para marujos descontentes. Depois de desertar de um navio mercante e gastar todo seu dinheiro na farra, o americano George Thompson, usando o nome de Michael Murray, decidiu se alistar no navio-depósito Madagascar, da estação naval da Marinha britânica na baía, mas logo se arrependeu. Uma nova deserção foi planejada com seu camarada Matt, mestiço de indígena de Massachussets. No navio, eles compraram cachaça contrabandeada e embalada na pele, para poder aguentar o frio e cansaço da fuga a nado. Na noite combinada, George e Matt beberam demais. 0 primeiro, ao invés de fugir, acabou dormindo na própria maca; o segundo foi encontrado morto no mar no dia seguinte, com a pele contendo um resto do aguardente. Descoberto 0 plano, Thompson foi condenado a 48 chicotadas com o famoso cat-o-ninetails, chicote com nove cintas, com um ou dois nós nas pontas. Na noite antecedente ao castigo ele conseguiu desertar, pulando de uma escotilha. 
89

THOMPSON, George (pseud.). Op. Cit., p.111-121.

90

MELVILLE, Herman. Op. Cit., p.572.

91

Ibidem, p.585-586.

92

Ibidem, p.404.

93

Ibidem, p.403.
Não foi capaz de alcançar as margens da cidade a nado e subiu ao convés de um brigue brasileiro. Logo anunciou aos tripulantes: "Yo soy um saltador inglês". Todos riram e lhe deram abrigo e comida. Na manhã seguinte trocaram roupas, e o desertor ganhou uma carona até a cidade no bote, do navio. ${ }^{89}$ Thompson fazia parte do grande grupo de marinheiros que inferiorizava culturalmente os latinos, os católicos e afins. Mas isso não o impediu de louvar a camaradagem dos brasileiros que lhe salvaram a pele.

Os oficiais podiam desembarcar fora do tempo de serviço e frequentar a cidade. Já seus subordinados estavam submetidos a políticas variáveis, mas sempre restritivas. Em White Jacket, Herman Melville dedica um capitulo sobre a liberdade em terra, "liberty", dos marinheiros. Em nome de toda a tripulação, Jack Chase, o mais "corajoso e culto", pede liberdade ao capitão e ao Comodoro citando Shakespeare, Homero e o poeta inglês Robert Anderson. Compara os marinheiros a camelos sedentos pelo verde e pela água do oásis: "Não estamos vindo do oceano Saara? E o Rio não é um lugar verdejante, nobre Capitão?"90.

Os oficiais concederam 24 horas para todos, divididos em quatro grupos. Um dos grupos não voltou no prazo. Foram caçados pela cidade e voltaram "em todos estágios imagináveis de embriaguez: alguns com olhos roxos e contusões na cabeça". Durante essas idas e vindas, o narrador lamenta esta "triste cena" do navio, comparando-o a um hospício, que ressoava a "lutas, gritos e canções frenéticas". ${ }^{91} 0$ narrador-personagem da novela, o marujo White-Jacket, não era favorável ao grogue. Ele chega a aconselhar um colega, dizendo que o álcool estava Ihe destruindo. 0 mesmo lhe responde: "Largar o grogue? Por quê? Por que está me arruinando? Não, não; eu sou um bom cristão, e o amor que tenho pelo meu inimigo não permite abandoná-lo" ${ }^{\text {"92 }}$. White Jacket explica o que entende ser 0 amor ao grogue: "para muitos deles, a expectativa do trago (tot) diário cria uma sequência perpétua de paisagens deslumbrantes e evanescentes com a distância. É sua grande perspectiva na vida. Tire o grogue deles e a vida não possui mais nenhuma graça"93.

A bebida alcoólica era um vício, em parte justificável no meio naval, não só por quem a consumia em demasia, quanto para aqueles que conheciam o cotidiano do trabalho no mar. Em seu diário, o escrivão Daniel Noble Johnson refere-se, várias vezes, à questão da liberdade dada aos marujos e sua associação com a bebida alcoólica. Como ele ficou por mais de dois anos na estação naval americana no Rio de Janeiro, sua reflexão é especialmente interessante.

Em 26 de dezembro de 1841, depois da missa, o capitão do navio de Johnson liberou grupos de cerca de 100 marujos cada vez (imagino o impacto na cidade), Ihes dando três dólares para gastar em terra. Segundo o escrivão, a quantia era gasta nas primeiras horas, e alguns homens vendiam as roupas para poder usufruir todas as horas que tinham direito. Dois dias depois, a maioria voltou completamente bêbada e alguns foram confinados. Apenas seis desertaram e três foram presos. Um deles, W. Brown entrou num café francês quebrou todos os móveis e bateu no atendente até mata-lo. Foi para o calabouço, onde esperaria o julgamento da Justiça brasileira. Johnson lamentou, pois ele era um "dos mais inteligentes marítimos do navio", e tinha um "excelente caráter". Para o escrivão isso demonstrava "a que estágio o diabólico rum levava um homem" 94 .

Johnson anunciou uma dúvida que retomaria ao longo dos anos que fica na estação: "o lado bom e ruim desta política está para ser medido". A li- 
berdade era uma barganha entre oficiais e marujos. Depois de breves desembarques eles poderiam ficar meses sem descer do navio: "as piores descrições de devassidão e bebedeira aconteciam nestas ocasiões, e eles são perdoados quando voltam depois dos excessos cometidos enquanto estavam livres" ${ }^{\prime \prime 2}$. Era ruim por alguns dias, logo que os marujos voltavam, mas era um mal necessário para os longos períodos de trabalho extenuante. 0 próprio escrivão observou que era impossivel não ceder alguns dias para homens confinados num navio por meses ou anos. De certa maneira, apesar de ter muitos mais direitos que os subordinados, os oficiais compartilhavam algumas de suas dores. Como os seus subalternos, eles também ficavam anos longe da família e muitos deviam consumir álcool em grandes quantidades.

Um ano depois, durante outro período de desembarque ou "liberdade", Johnson acentua bem a diferença dos oficiais com os marinheiros, os quais ele descreve como "um pouco menos que escravos absolutos, e às vezes submetidos aos feitores mais duros. Muitas vezes, privados de noites de sono, suas vidas, membros e saúde em constante risco". Por isso, "eles se dirigem à cidade com os corações transbordando de esperança". Depois de toda esta empatia, ele enfatiza a diferença de classe e grau de civilização, os comparando com "índios selvagens fazendo bagunça na praça do Palácio".96 Mira Glenn demonstrou que se por um lado marinheiros memorialistas confirmam o estereótipo do marinheiro farrista e beberrão, por outro justificam esta atitude como uma pausa da dura e humilhante vida marítima. Além disso, beber era um direito do marinheiro como homem livre ${ }^{97}$, num tempo em que a escravidão ainda grassava no Atlântico.

Em 1843, mais um ano se passou, e os marujos do navio de Johnson haviam conquistado liberdade por 24 horas todos os meses. 0 autor finalmente defendeu esta política, argumentando que a frequência de saída mensal por um dia resultava na volta dos rapazes no tempo regulamentar e mais alinhados. Quando eles desembarcavam cada seis meses por dois, três dias, naturalmente voltariam bêbados demais, tantos outros sem as roupas, ocorreriam tragédias, outros desertariam, como aconteceu no começo da estadia na baía. ${ }^{98}$

Além das notícias de vários distúrbios envolvendo marujos, seu desembarque era também uma experiência estética para os nativos da cidade. Já como jornalista, o ex-marinheiro Charles Nordhoff fez quase uma ode à roupa maruja em suas memórias:

Azul é a roupa de trabalho do marinheiro, branca é a roupa dos dias de folga. [...] 0 verdadeiro marinheiro de guerra é muito particular nas suas vestimentas. Não há alguém mais dandy que ele. Não há janota da Broadway que preste mais atenção ao corte de seus indescritiveis ornamentos, o caimento de seu colarinho, no nó de seu lenço, ou no lustre imaculado de seus sapatos [...] por muitas horas ele faz pose diante de seu espelhinho redondo de bolso [...] para alcançar tal visual original. [...] Olhe para seu colarinho azul disposto com graça sobre seus ombros largos, em torno de seu pescoço bem torneado, seu chapéu inclinado com estilo sobre a sobrancelha esquerda, uma mão colocada displicentemente no quadril e ninguém precisará te dizer que você está diante de um marujo. ${ }^{99}$

Muitos marujos vestiram suas melhores roupas brancas ou azuis, quando o navio aportava, para verem e serem vistos, quando eram visita- 
100

THOMPSON, George (pseud.). Op. Cit., p.88-89.

101

BARRA, Ezekiel I. Op. Cit., p.85.

102

MELVILLE, Herman. Op. Cit., p.586.

103

JEHA, Silvana Cassab. A galera heterogênea... 0p. Cit., p.96-102.

104

JOHNSON, Daniel Noble. Op. Cit., p.59. dos e quando visitavam a cidade. No Rio, George Thompson comparou os marinheiros militares americanos com os das demais nações, elegendo-os os mais elegantes: "suas vestimentas de tecido fino eram bem feitas, camisa de flanela azul escura bordada com seda preta, estrelas brancas de seda bordada em cada canto do colarinho, e nos seus chapéus o nome do navio bordado com letras de seda dourada". 100

Antes do marinheiro Ezekiel I. Barra desembarcar no Rio em 1849, vestiu seu terno de verão, comprado em Cuba: calça e paletó de linho branco, camisa branca, sapatos marroquino, chapéu Panamá. Ele afirmou adotar o conselho de Apolonio na partida de seu filho Laerte, quando desembarcasse num país estranho, em Hamlet: "o vestuário denuncia o homem"101. As características de sua roupa também denunciam como a moda marinheira poderia ser uma combinação internacional e sugere que os chamados malandros cariocas ligados ou não à história do samba e entidades dos espíritos chamados de malandros na Umbanda ,como o Seu Zé Pelintra, compartilharam o terno branco pelo menos desde o início do século XX. Estes mesmos malandros, hoje em dia tão estilizados e estereotipados quanto os marinheiros, também usam blusas listradas em terreiros, carnaval, sambas e outros rituais e festas. Como vimos acima, alguns marujos vendiam suas roupas quando desembarcavam pra usufruir mais dos dias de folga. Quando desertavam também, já que eram os poucos bens que dispunham para sobreviver até embarcar num outro navio. Numa de suas deserções, George Thompson vendeu suas roupas para açougueiros na Ilha do Governador.

Em vários portos do planeta, havia um costume de mulheres frequentarem os navios, levadas pelos bumboats ou botes de quitanda. Ainda não encontrei registros no Rio de Janeiro. Melville menciona em White-Jacket que este era um hábito do passado na Marinha americana. ${ }^{102}$ Mas, imagino ser algo possivel até os dias de hoje.

0 marujo americano Jacob Hazen manteve um curto e intenso romance com a prostituta inglesa Mary Mertle enquanto morou no Rio de Janeiro. Ao que parece, ele não tinha uma relação apenas de cliente com a inglesa: quando ela adoeceu, foi Hazen quem Ihe deu todos os cuidados. Mary morreu e foi enterrada na vala comum da Santa Casa de Misericórdia, destino dos corpos de escravos, mendigos e outros desvalidos. Horrorizado com o triste fim de sua "lady-love", decidiu deixar o Rio de Janeiro, durante uma madrugada de 1838, enquanto chorava diante da Santa Casa. ${ }^{103}$

0 escrivão Daniel Johnson, como outros marítimos, apenas sugere encontros afetivos ou sexuais. Ou talvez, na maioria dos casos, explicitar relações sexuais não era recomendável no meio editorial do período, e aqueles que o fizeram em seus manuscritos podem ter sido censurados. Johnson refere-se às mulheres como musas e deixa transparecer uma atitude de admiração e arrebatamento, que credita à vida solitária da profissão. Ele amava as "Mademoiselles of la belle France" da Rua do Ouvidor, onde dezenas delas trabalhavam ou mantinham lojas de costura:

Apenas o marinheiro depois de semanas, meses longe de mulheres, pode apreciar completamente suas atrações. A mulher é sempre [...] a coisa mais importante que ele pode encontrar numa viagem; e quando contrastada com os rudes companheiros com quem navega os mares, ele é arrebatado, e a primeira que encontra seus olhos, não importa seu garbo, lhe parece um anjo perfeito, e ele olha ardentemente para ela e todo seu sexo com a alma aberta em admiração, mergulhando em seus olhos. ${ }^{104}$ 
105

Ibidem, p.186.

\section{6}

FLETCHER, James.C. Rio de Janeiro chaplaincy, August, 19, 1853 - Rev. J. C. Fletcher, Chaplain. The sailor's magazine, American Seamen's friend society, v.XXVII, n.3, p.92, november 1853.

107

As organizações missionárias em prol dos marujos começaram na Inglaterra nas últimas décadas do século XVIII, e proliferaram dali em diante. Em 1816, um grupo metodista criou uma bandeira para sinalizar em que navio do porto de Londres estava sendo realizado um culto. A bandeira tinha a palavra Bethel (Casa de Deus no antigo testamento), um pássaro e uma estrela. Essa prática atravessou o oceano inspirando entre outras a fundação da American seamen'sfriend society, uma organização protestante multinominal. KVERNDAL, Roald. Seamen's missions: Their origin and early growth. Pasadena, CA: William Carey Library, 1986.

108

Report of Rev. O. M. Johnson. The sailor's magazine and naval journal, The American seamen's friend society, New York, v.10; KVERNDAL, Roald. Op. Cit., p.251.

109

BATES, Joseph. Autobiography of elder Joseph Bates, embrancing a long life on shipboard. BattleCreek, Mich.: Steam Press of the seventh-day Adventist publishing, 1868. p.220.
Mas Johnson preferia as morenas ("brunettes") e "as brasileiras eram notórias por esta compleição". Em 4 de setembro de 1844, dia do casamento de Pedro II e Teresa Cristina, o marítimo participou dos festejos da cidade abarrotada de gente. Ele ficou extasiado ao ver mulheres solteiras nas ruas. Reclamou que era costume no Brasil guardar as mulheres solteiras em casa. Mas neste dia as viu em quantidade: "o brilho de seus olhos apagava as luzes dos arcos, e a música desaparecia com suas alegres conversas em português". Ele e outros marítimos americanos "não sairam ilesos destes bobardeios e tiveram de se render a estas belezas do sul". Johnson acabou sua noite no Hotel Pharoux frequentado por estrangeiros mais abonados se sentindo "all right". À meia-noite um encarregado gritou: "botes nas escadas"! ${ }^{105}$ Isto significava, bote nas escadas da praça do Palácio, fim da festa, hora de voltar para o navio. A farra dos oficiais também tinha tempo marcado, pois a maioria morava nos navios.

\section{Protestantismo na baía}

\begin{abstract}
A bandeira Bethel ainda flutua, e sob suas dobras pacíficas reúnem-se, de domingo a domingo, o enérgico capitão desbravador do mundo todo, o aventureiro atrás do ouro da Austrália, os ricos garimpeiros da Califórnia e o marinheiro americano, este habitante robusto do castelo de proa, com quem ninguém se importava trinta anos atrás, mas para quem agora capelas são construídas, missionários enviados, tratos e bíblias impressos e milhares de preces elevadas Àquele que acalma o barulho das ondas. [salmo 65] ${ }^{106}$
\end{abstract}

Missas flutuantes ocorreram na baía do Rio de Janeiro, celebradas pelo Reverendo James Fletcher, autor destas palavras, e diversos outros estrangeiros. Em 1821, foi fundada em Nova York a American Seaman's friends society. Seu objetivo era "melhorar as condições morais e sociais dos marítimos [...]; promovendo em todos os portos [do mundo], abrigos, hospedagem, poupanças, [...] bibliotecas, salas de leitura e escolas - e também a pregação do Evangelho e outras benções religiosas" 107.0 reverendo Fletcher, mais conhecido pelo livro que escreveu sobre o Brasil, foi também missionário desta instituição entre 1851 e 1854.

A partir de 1821 até pelo menos 1854, intermitentemente, houve cultos sob a bandeira Bethel no porto do Rio de Janeiro. Até 1834, a bandeira tremulou em embarcações americanas e inglesas, e os cultos foram realizados por um "capitão Bethel" de navio mercante inglês e dois negociantes britânicos residentes no Rio de Janeiro. ${ }^{108}$ Depois de 1835, a American seaman's friends society enviou, com outras instituições cristãs, missionários para atender marítimos e passageiros e outros protestantes no porto do Rio de Janeiro e evangelizar principalmente marinheiros de todas as nacionalidades.

Em 1827, o capitão americano Joseph Bathes, anos mais tarde, um dos fundadores da Igreja Adventista do Sétimo Dia, assistiu missa na baía num navio inglês com a bandeira Bethel hasteada. 0 ritual lhe pareceu formal e aborrecido, o que esvaziava sua profundidade espiritual. Para completar, os oficiais presentes foram convidados para a cabine onde havia uma mesa cheia de bebidas alcoólicas. Desapontado, Bates voltou para o seu navio, onde dias depois realizou uma reunião de orações com amigos "abençoada pelo céu"109. 0 americano escreveu suas memórias décadas depois de ter comerciado na costa brasileira, e todo o discurso no livro segue uma lógica de conversão e de preparação espiritual simultânea ao sucesso 
WEBER, Max. A ética protestante e o espirito do capitalismo. São Paulo: Editora Pioneira, 1996. p.85.

112

FLETCHER, James. Rio de Janeiro March 3rd, 1853 Rev. J. C. Fletcher, Chaplain. The sailor's magazine, New York, American Seamen's friend society, v.XXVII, n.3, p.92, november 1853.

113

Report of Rev. 0. M. Johnson. Op. Cit. econômico. Curioso é que no mesmo parágrafo ele afirma que deixou a baía, pois as autoridades da alfândega "negaram a liberdade de vender minha carga no Rio de Janeiro"110. Ele então partiu para Santa Catarina, onde obteve bons resultados vendendo farinha de mandioca, depois expedida para as tropas do Rio Grande do Sul. Bates estava praticando comércio de cabotagem na costa brasileira, algo proibido para navios estrangeiros. Ele insistiu na ilegitimidade dessa lei, e descreveu como ele a burlava, vendendo cargas em províncias em estado de guerra ou de fome. Inevitável evocar a Ética protestante do Capitalismo de Max Weber: "Um dos elementos fundamentais do espirito do capitalismo moderno, e não só dele, mas de toda a cultura moderna, é a conduta racional baseada na ideia de vocação nascida [...] do espírito do ascetismo cristão"111. Bathes mistura estas duas etapas da sua formação religiosa e capitalista nas viagens de comércio que empreendeu na América do Sul, sobretudo na costa brasileira, onde ganhou muito dinheiro praticando comércio de cabotagem ilegal. 0 seu relato procura demonstrar que as revelações religiosas implicaram na abdicação do gozo de prazeres carnais como bebida, tabaco e a observância dos dias santos, o que resultou no sucesso nos negócios, rompendo todas as dificuldades e obstáculos do comércio maritimo.

Quase três décadas depois, o reverendo James Fletcher relatou que visitava cada navio americano ancorado na baía num barco "remado por um negro e um homem da ilha de Madeira" que se admiravam ao ver o "padre americano" debaixo de um sol de mais de 30 graus subindo no convés de cada navio dos "Estados Unidos". Em 28 de novembro de 1852, 0 resultado, segundo o pastor, teria sido reconfortante. Ele celebrou a missa no convés do brigue Fanny, sob um sol de quase 40 graus, para uma grande audiência, sob a inspiração de Pedro, capítulo quatro, versículo oito: "tende antes de tudo ardente amor uns para com os outros, porque o amor cobre uma multidão de pecados".112

Como vimos na seção acima, frequentar bordeis ou estalagens não era um problema para o funcionamento do navio, ao contrário, era muitas vezes um acordo tácito para conter a tensão causada pelo confinamento. Os religiosos, por sua vez, não compreendiam assim. Raramente se colocavam no lugar dos fiéis que tanto tentavam amealhar. 0 reverendo Obadiah Johnson da Seamen's friends society esteve em pelo menos seis estalagens para maritimos pertencentes a anglófonos no Rio, as quais, na sua opinião, não passavam de groggeries, lugares em que "velhos e jovens marinheiros passavam a tarde de domingo falando alto, cantando, bebendo, alguns dormindo sobre as mesas e a maioria estúpidos demais para aproveitar algo que se pudesse dizer a eles." 0 reverendo entregava folhetos religiosos aos que ele chamou de "mais soberbos" e "os alertava da necessidade de deixar aquele lugar de pecados e voltar aos seus navios". ${ }^{113}$

Um dos grandes objetivos dos missionários era convencer marinheiros a não passarem o domingo (sabbath) divertindo-se no porto e, sim, reservar o dia santo para os rituais cristãos. Pelos seus relatos, em terra, eles não atuaram muito nos locais de diversão e concentraram-se nas missas e no atendimento aos doentes. Os marujos não deixaram necessariamente de lado a diversão a favor da religião. Isso não significa que eles não atenderam a esses dois apelos. Deveria ser difícil abrir mão dos prazeres carnais, sexuais ou etílicos, mas a ideia do culto na sua língua e da leitura eventual da bíblia também era bem-vinda. Joseph Clark, um marinheiro religioso pregador não concordava. Perguntou no prefácio de suas memórias: "De 
114

CLARK, Joseph G. Op. Cit., p.VI.

115

FLETCHER, James C. [American seamen's chaplain, Rio de Janeiro] Brazil chaplaincy. Rio de Janeiro, May 11, 1852. To the secretaries of the American Seamen's Friend society. The sailor's magazine, American Seamen's friend society, v. XXV, n.3, p.80-81, nov/1852.

116

Idem. Rio de Janeiro, March 3rd, 1853, Rev. J. C. Fletcher... 0p. Cit., p.92.

117

Idem. The sailor's magazine, v.XXVI, September, 1852, p.4-5.

118

Religioso inglês do que viveu no século XVIII, cujo hinário continua bastante difundido entre diversas igrejas protestantes até hoje. Este hino é baseado num versículo da Bíblia (II, São Paulo, 5:1).

119

FLETCHER, James C. The sailor's magazine, v.XXVI, September, 1852, p.4-5. que adianta um marítimo assistir à missa de domingo, e no tempo restante se misturar com a sociedade corrompida do bordel?"114

James Fletcher descreveu as agruras da vida marítima, como se as sentisse, mas exigia, depois de tanto sofrimento - religioso que era - apenas uma atitude da parte dos marujos: a temperança:

0 marinheiro vem abalado depois de um ou dois meses navegando. Provavelmente vem do inverno, dos ventos gelados do cabo Hatteras ou ele pode ter dobrado o tempestuoso cabo Horn. De repente numa manhã de sol, as montanhas que circundam a cidade aparecem na distância e em poucas horas ele aporta no seio de águas tranquilas dessa baía sem igual. Ele está numa região de perpétua beleza primaveril, tempestades de inverno jamais acontecem nessas águas, frutas e flores penduradas em árvores e trepadeiras selvagens durante 0 ano todo; a primavera e 0 verão jamais acabam. Ainda que ele tenha escapado de tempestades ele não escapa do trabalho aqui. 0 cordame tem de ser reparado, pintura e reparos feitos, a carga desembarcada e uma nova de café carregada. Os homens do castelo de proa durante os dias de semana suspiram pela sombra das palmeiras que acenam, ou o verde que cobre as montanhas que ele vê ao seu redor. Não há pausa para o trabalho até domingo chegar. Então seus desejos latentes pela terra não Ihe impelem a atender aos serviços religiosos sinalizados num navio pela bandeira bethel. Ele obtém a licença para desembarcar, e nove entre dez não visitam os bosques verdejantes, mas são seduzidos por alguma rua estreita e quente da cidade onde ele encontra um escuro covil de bebidas. E no fim deste dia ele volta para o navio bêbado, motivo de gozação de seus companheiros e de desespero para os oficiais. ${ }^{115}$

Como os outros missionários que não sabiam a língua dos becos e tavernas, Fletcher concentrou-se no atendimento a doentes no hospital, principalmente aqueles com febre amarela, e enterrou muita gente no período que ficou no Rio. Em 1852, ele relatou que em alguns navios, metade de sua tripulação morrera e em outros, quase todos. ${ }^{116} 0$ pastor se dispôs a escrever cartas para os pais dos falecidos. Um deles foi James Libby. A carta endereçada aos pais foi publicada na revista da Seamen 's friends society. ${ }^{117}$ Em março de 1853, Fletcher o visitou no brigue Rhone, falou repetidamente sobre Cristo para um homem, cuja fé estava abalada e foi visitar outros doentes. No dia seguinte, James morreu, mas o companheiro que estava ao seu lado, relatou que momentos antes ele vira Jesus que lhe falou: "Eu perdôo seus pecados". Em seguida, James exclamou "Estou feliz! Feliz!" 0 capitão do navio e seu amigo começaram a cantar hinos cristãos, o moribundo procurou ler o livro que eles lhe mostravam e repetiu várias vezes o último verso do hino de Isaac Watts"11: "Há uma casa construida sem mãos, eterna nas alturas. E ali meu espírito está esperando até que Deus o faça voar." Estas seriam suas últimas palavras antes do vômito negro que anunciava a morte por febre amarela. Fletcher realizou seu enterro no cemitério da Gamboa, da onde, nas suas palavras,

se tem uma magnifica vista da baía das águas da baía do Rio de Janeiro, e mais ao longe, erguem-se em direção aos céus os picos da Serra dos Órgãos. Esta baía pode secar e os seus picos desaparecerem, mas as almas daqueles que morreram no Senhor nunca, nunca, deixarão aquela bem-aventurada morada. ${ }^{119}$

0 missionário contrastou aqueles que morreram na graça da fé com os que a abandonaram. Seguiu um americano doente que trabalhava numa loja de artigos marítimos até um hospital particular para lhe evangelizar. Até o último momento ele negou a religião, e segundo Fletcher, aqueles que viram sua morte, disseram que sua cara de terror era insuportável. 
120

Idem. Brazil chaplaincy. Rio de Janeiro, May 11, 1852... Op. Cit., p.80-81.

121

HAZEN, Jacob. Op. Cit, p.213-214.

122

Ibidem.

123

Ibidem, p.307.

124

GLENN, Myra C. Op. Cit., p. 150 .
Dias antes o missionário the oferecera uma biblia que ele recusou. Fletcher estranhou duplamente essa recusa, uma vez que o homem, cujo "esqueleto tremia a beira da morte", segurava uma novela de Dumas. Enfim, o anônimo não cedeu nem quando no último suspiro moribundo, o que no ponto de vista do missionário resultou numa morte horrenda. De qualquer modo, Fletcher deixou um registro bonito a seu respeito, o rapaz gostava de sua visita, não como pastor, mas como alguém que se preocupava com ele. ${ }^{120}$

Depois de sua estadia no Rio de Janeiro, o marujo Jacob Hazen narrou a tentativa de uma missionária de convertê-lo, ou torná-lo um religioso no porto de Boston. Ele estava cumprindo um castigo, preso em ferros e lendo uma novela, no convés do navio. Ela Ihe abordou e queria convencê-lo que a leitura de novelas não instruia, e que ele devia se preocupar com o bem estar de sua alma imortal, enquanto lhe oferecia tratos religiosos. Hazen respondeu que novelas divertiam, e era isso que ele queria, uma vez que "sua alma já deveria estar danada", respondendo ao gesto da missionária com o barulho dos ferros que o prendiam e se referindo, em seguida, à crueldade dos oficiais com os subordinados. ${ }^{121}$ Com um discurso mais politizado, Hazen explica ao leitor:

\footnotetext{
não há nada mais irritante para uma mente sensivel numa situação de injustiça e degradação, do que conversar com pessoas que ignorem completamente sua condição, pensamentos e sentimentos e consequentemente incapazes de conquistar sua simpatia ou aliviar seu sofrimento. ${ }^{122}$
}

Se por um lado Hazen era esclarecido, devido a suas viagens, leituras e disposição para o conhecimento, por outro adquirira os mesmos preconceitos e polarizações que seus conterrâneos, eruditos ou não, tinham a respeito de populações latinas e católicas. Se não era protestante praticante, era oriundo de uma cultura protestante. Para ele, "os nativos dos países católicos devotavam um terço do tempo à dança e à festa [...] mesmo tempo este que em comunidades inteligentes é empregado em estudos de livros, ou alguma recreação intelectual"123.

Os missionários certamente granjearam fiéis (como até hoje o fazem), seja por sua retórica, ou empatia verdadeira. Segundo Myra Glenn, apenas uma minoria de marítimos abandonou as farras no porto devido aos preceitos cristãos. ${ }^{124}$ Os marujos que aderiram à prática religiosa em situações dificeis encontraram nela um alívio para os seus sofrimentos. Outros, menos crentes, optaram por uma visão crítica da religião, ocupando sua mente com outras leituras populares ou eruditas, incluindo a leitura da Bíblia.

\section{Considerações Finais}

Declínio da era dos navios veleiros; o Rio de Janeiro como uma das escalas principais das rotas internacionais; ascensão do comércio dos Estados Unidos com o Império do Brasil; projeto de expansão naval americana oitocentista; uma florescente narrativa marítima americana formaram o cenário para este artigo, que escrevi junto com seus personagens: marítimos escritores.

Outros paises também tiveram presença fundamental neste porto, quais sejam Inglaterra, França e Portugal. Mas até onde eu pude pesquisar, com exceção talvez da Inglaterra, não deixaram um conjunto de testemunhos de tamanha envergadura sobre o Brasil, como os americanos. Enfim, o contexto geo-político-econômico enumerado acima, aliado a outro, cultural, resultou nestas narrativas. 
125

A maior parte destas informações foram extraídas das próprias memórias dos maritimos.

126

GLENN, Myra C. Op. Cit., p.31
0 Rio de Janeiro era a capital de um Império, abrigava estações navais de outros países, foi alvo de missões evangélicas - provavelmente as primeiras da nova nação - cultura, hoje em dia, que tem um impacto na vida e religiosidade dos brasileiros. Por isso a cidade foi intensamente registrada na documentação marítima do século XIX. A cidade, onde estas histórias aqui recontadas aconteceram, era uma encruzilhada de gente local e estrangeira em permanente movimento, que não pode ser ignorada na historiografia do Império, de sua cultura e de sua sociedade. As grandes cidades portuárias são, afinal, uma via de duas mãos onde o local se internacionaliza e contamina o internacional.

\section{Sobre os autores ${ }^{125}$}

AMES, Nathaniel. A mariner's sketches, Providence (EUA): Cory, Marshall \& Hammond, 1830. Nathaniel Ames (1796-1835) estudou em Harvard e pertencia à uma família importante de Massachusetts. Tornou-se marinheiro, segundo Myra Glenn, "na esperança de trocar a vida de frivolidade e dissipação pela disciplina requerida em longas viagens marítimas". ${ }^{126}$

BARRA, Ezekiel I. A Tale of Two Oceans; A New Story by an Old Californian: An Account of a Voyage From Philadelphia to San Francisco around Cape Horn, years 1849-50, Calling at Rio de Janeiro, Brazil and Juan Fernandez in the South Pacific. San Francisco. 1893. Ezekiel Barra começou a vida como marinheiro. Em 1849, na Filadélifia, resolveu participar da corrida do ouro e embarcou num navio para Califórnia como passageiro. Durante a viagem, empregou-se como marinheiro da embarcação. 0 navio aportou no Rio de Janeiro em 20 de dezembro de 1849 e permaneceu 30 dias na cidade, o que rendeu 40 páginas de sua memória. A viagem até São Francisco durou cerca de seis meses. As suas memórias foram publicadas 43 anos depois, em 1893. No prefácio, ele justifica que só pode fazê-lo, pois estava aposentado. 0 livro seria resultado de uma adaptação do diário que manteve durante a viagem.

BATES, Joseph. Autobiography of elder Joseph Bates, embrancing a long life on shipboard. BattleCreek, Mich.:Steam Press of the seventh-day Adventist publishing, 1868. Joseph Bathes (1793-1872) cresceu na cidade maritima de New Bedford, na área que depois se chamaria Fairhaven. Aos 15 anos embarcou como grumete na sua primeira viagem marítima para a Europa. Anos depois foi forçado a servir na Marinha britânica e tornou-se prisioneiro em Dartmoor, Inglaterra. Voltou para os Estados Unidos onde seguiu carreira marítima até tornar-se capitão. Entre 1821 e 1828 empreendeu diversas viagens para o Atlântico sul, principalmente na costa brasileira. Neste período passou por uma série de experiências místicas e, aos poucos, tornou-se religioso profissional. Na década de 1860 foi um dos fundadores da Igreja Adventista do Sétimo Dia, hoje uma das maiores igrejas protestantes do mundo, com miIhões de fiéis espalhados por todos os continentes, inclusive no Brasil. A maior parte destas informações foram extraídas de suas memórias.

BRIGGS, Charles. (1804-1877). The adventures of Harry Franco: a tale of the great panic. New York: F.Saunders, 1839. Charles Briggs nasceu em Nantucket, foi marinheiro na década de 1820, tornou-se comerciante e depois jornalista em Nova York. Trabalhou com Edgar Allan Poe no Broadway Journal. Adventures of Harry Franco é uma novela baseada em sua experiência marítima, publicada em 1839, sem o seu nome. Desde então, também ficou conhecido como Harry Franco. Posteriormente escreveu outras novelas marítimas.

BUNNEL, David Curtiss. The travels and adventures of David C. Bunnell during twenty three years of a sea-faring life; containing an accurate 
account of the battle on lake Erie,(..); together with ten years service in the navy of the United States - also - service among the greeks, imprisonment among the turks, etc. etc. Palmyra, NY: J. H. Bortles, 1831. Bunnel nasceu em Connecticut em 1793. Ficou órfão de pai aos dois. Mudou-se com sua família para Nova York, mas sua mãe o deixou só na cidade, com apenas onze anos, trabalhando como aprendiz de artesão. Insatisfeito com o trabalho e sem familia, começou a sua vida de maritimo. Participou da bataIha americana do Lago Erie. No Mediterrâneo foi tomado como prisioneiro pelos turcos. Viajou algumas vezes para América do Sul, primeiro como recrutado à força pela Marinha inglesa, depois como engajado na marinha americana e, posteriormente, a bordo de um navio mercante americano, num navio português e num navio de guerra brasileiro. Depois de 23 anos no mar, decidiu-se pela terra firma e escreveu suas memórias.

CLARK, Joseph G. Lights and shadows of sailor life, as exemplified in fifteen years'experience, including the more thrilling events of the U.S. Exploring Expedition of a eventful life on the mountain wave. Boston: Benjamin B.Mussey \& Co, 1847. Joseph Clark foi um marinheiro religioso que participou da U.S. Expedition de 1838-1842. Aportou no Rio de Janeiro em 1838, onde desembarcou. Ele narra sua experiência na cidade da página 26 a 33.

HAZEN, Jacob. Five years before the mast or Life in the forecastle, aboard of a whaler and man-of war, Philadelphia: G.G. Evans: 1859. Hazen nasceu na década de 1810 em Muncy, Pensilvania. Tornou-se aprendiz de sapateiro aos cinco anos. Muito cedo, separou-se da família e foi exercer esta profissão na Filadélifia. Durante o Grande Pânico de1837 (crise econômica americana), resolveu embarcar num baleeiro. Desertou no Rio de Janeiro, onde viveu alguns meses e acabou se alistando na Marinha americana na Estação Naval sediada na baía da cidade. Depois de viajar por mais de três anos na Marinha de guerra, voltou para os Estados Unidos em 1842, onde, ao que parece, retomou a profissão de sapateiro.

HOLBROOK, Samuel. Threescore years: An autobiography containing incidents of voyages and travels including six years in a man-of-war... Boston: James French \& C., 1857. Holbrook nasceu em 1793. Na década de 1810 fez sua primeira viagem como aprendiz num navio mercante e tornou-se carpinteiro de navio. Assentou praça na Marinha americana, participou da chamada Guerra Algeriana, ou "Segunda guerra contra os bárbaros" em 1815. Entre 1819 e 1821 estava embarcado na fragata Macedonia, cuja missão era proteger os navios americanos durante as guerras de independência na costa oeste da América do Sul. Esteve no Brasil quando voltava desta viagem. Escreveu as memórias em 1856.

JOHNSON, Daniel Noble. The journals of Daniel Noble Johnson (18221863) United States Navy. Edited by Mendel L. Peterson. Smithsonian Miscellaneous Colletions, V. 136, n. 2. Washington, Smithsonian Institution, 1959. Johnson (1822-1863) nasceu em Nova York numa família de classe média. Aos 19 anos, ingressou na Marinha americana como escrivão do navio Delaware. Desde o primeiro dia escreveu um diário. Ficou no Brasil entre 1841 e 1843. Depois trabalhou como funcionário público e comerciante. Durante a guerra civil juntou-se às Forças Armadas novamente. Seu diário foi guardado pelos netos e, em 1959, foi publicado nos anais do Smithsonian Institution.

MACAULAY, Hastings W. Kathay: a cruise in the China seas. New York, G.P. Putnam \& Co., 1852. Macaulay era oficial e participou deste cruzeiro da Marinha americana para os mares da China entre 1850 e 1852. Esteve no Rio de Janeiro em 1850. 
127

THORP, Willard. Op. Cit., p.403-440.
Recebido para publicação em março de 2013 Aprovado em outubro de 2013
MELVILLE, Herman. White-jacket or the world in a man-of-war. London: Richard Bentley, 1850. Como Moby Dick, White Jacket foi inspirado na sua experiência de marujo, só que num navio de guerra. Ele escreveu este livro em dois meses no verão de 1849. A história é baseada numa viagem de 14 meses que fez como marujo no United States, uma fragata de guerra americana, entre 1843 e 1844. Parte autobiográfico, parte ficção, o navio de fato aportou no Rio de Janeiro do dia 16 a 24 de agosto de 1844. Willard Thorp demonstra que, além de suas lembranças, a obra contém transcrições e adaptações de verbetes enciclopédicos, memórias marítimas de outros autores, entre outros. ${ }^{127}$ Melville publicou Moby Dick em 1852 e não obteve muito êxito. Morreu em Nova York, sem qualquer reconhecimento.

MORRELL, Capt. Benjamin. A narrative of four voyages to the south sea, north and south pacific ocean, Chinese sea, Ethiopic and southern atlantic ocean, Indian and Antartic ocean. From the year 1822 to 1831. New York: J\&J Harper, 1832. Benjamin Morrell nasceu em 1793 no estado de Nova York e quando jovem fugiu de sua família classe média para se aventurar como marinheiro nos quatro cantos do mundo. 0 filho pródigo voltou à casa e acabou tornando-se capitão de um baleeiro, onde estava embarcado quando visitou o Rio de Janeiro.

NORDHOFF, Charles. Nine years a sailor: Sketches of personal experience in the United States Naval Service, the american and British Merchant marine, and the whaling service. Cincinnat, USA: Moore, Wilstach \& Baldwin: 1866. Nordhoff (1830-1901) nasceu em Westfalia e migrou para os EUA aos 4 anos. Estudou e trabalhou como aprendiz em gráficas em Cincinatti e Baltimore. Na década de 1840, nesta última cidade, se engajou na marinha de guerra americana como $1^{\circ}$ grumete, aos 15 anos. Depois trabalhou na marinha mercante até 1853 , quando se tornou jornalista. Trabalhou no Philadelphia Register, New York Evening Post e New York Herald, além de escrever memórias marítimas e outras reportagens. Morreu na Califórnia. Nine years a sailor é a publicação de três volumes de memórias maritimas: Man-of-war life, The Merchant Vessel e Whaling and fishing. $\mathrm{Na}$ ordem, eles versam sobre a marinha de guerra, mercante e baleeira dos Estados Unidos. Foram escritos nas décadas de 1850 e 1860.

THOMPSON, George (pseud.). The story of a strange career: The autobiography of a convict, an authentic document.(Ed. Stanley Waterloo). New York: D. Appleton \& Co.: 1902. George Thompson é o pseudônimo de um nova-iorquino que foi marinheiro entre o final da década de 1850 e 1865 , quando resolveu deixar a costa leste e rumar para o oeste. Na Califórnia foi diversas vezes condenado por roubo e passou cerca de trinta anos em cadeias. Livre entre 1897 e 1898, escreveu suas memórias maritimas e os manuscritos foram editados pelo jornalista Stanley Waterloo. Este último autor também escreveu um prefácio e um posfácio, os quais foram fontes para estas informações biográficas. Segundo Waterloo, Thompson morreu numa cadeia antes de ver suas memórias publicadas. Ele aportou no Rio de Janeiro em torno de 1860 e a sua experiência na cidade é narrada entre as páginas 74 e 125.

WILKES, Charles C. (1798 -1877) Narrative of the United States exploring expedition during the years 1838, 1839, 1840, 1841, 1842. V.1. Philadelphia, Lea \& Blanchard, 1845. Charles Wilkes (1798-1877) entrou na marinha de guerra americana como aspirante e morreu almirante. Comandou a US Exploring Expedition (1838-1842) e participou da guerra civil americana. Esteve no Brasil em 1838, onde fez várias observações sobre a cidade e sobre africanos. 